\title{
Assessment of Social Infrastructure Due to Growth and Development in Roads: A Case Study
}

\author{
Joyoti Gayen ${ }^{1}$ and Debashis Sarkar ${ }^{2}$ \\ ${ }^{1 \& 2}$ Department of Agricultural Economics, Institute of Agriculture, Visva-Bharati, Birbhum, West Bengal, India \\ E-mail: joyoti_gn@rediffmail.com
}

\begin{abstract}
Rural connectivity is essential for the socio-economic development of rural areas. Various studies reveal that a higher socioeconomic progress is occurring in areas with paved roads for a long time. The linkages are either direct or indirect. It has been observed in this study that places with better transportation systems lead to improved accessibility to education, healthcare and drinking water facilities. It has been found that improved road infrastructure also increases the transport facility which gives better access to healthcare and education. It has been observed that enrolment in secondary/higher secondary schools increases due to access to rural roads.
\end{abstract}

Keywords: Rural Roads, Education, Health Care and Drinking Water Facilities, Social Mobility

\section{INTRODUCTION}

The main aim of road development is to provide infrastructural facilities and social transformation (Gerald, 1986). The development of a road network is the most important way for the benefits to trickle down to local inhabitants (Singh and Chauhan, 1984; Werner and Lucious, 1992).Studies reveal that better roads provide greater accessibility to educational, health, employment and market facilities. Levy (1996) identified that there exists a very clear causal linkages between rehabilitated road infrastructure and access to education. Physical access further plays an important role in achieving a number of Millennium Development Goals (Barret, Reardon \& Webb, 2001). Airey (1989) observed that construction and improvement of roads shorten the distance to the hospitals. Rural roads play an important role in the provision of physical access. Better access leads to availability of institutional credit and reduces the cost of borrowings (Ramchandaran and Swaminathan, 2002).

Other infrastructure facilities like access to fertilizer sale points, markets, credit infrastructure, extension services etc are also developed with the development of transport infrastructure (Throrat and Sirohi, 2002). A rural area is accessible when people can reach there in an acceptable time, and the risk of not getting there on time reduces due to better connectivity (Tighe, 2006). Improved road infrastructure also increases the transport facility through which the rural households are able to get better health care, education and credit facility. Rural urban linkages are developed through road improvement which helps in strengthening the backward forward linkages in agricultural sector (Narayanmoorthy and Hanjra, 2006). It has been observed that linkage between access and availability of healthcare as well as education of the society proves that physical infrastructure services are crucial for quality and availability of health and education, which affect welfare to a large extent (Agrnor and Dodson, 2006).

Terefe (2012) observed that better road facilitates utilization of existing social services such as education and healthcare which enhances the human capital of the poor in addition to the enhancement of productivity by fostering technology and information inflows. Jain (2014) observed a positive impact of increased accessibility to better educational facilities, reduced illness etc.

Research suggests that public investment in infrastructure especially in rural roads improves local community and market development; it is a key component of rural development and contributes significantly in the socioeconomic development of rural people by providing access to amenities like education, healthcare, marketing etc.

(Samanta, 2015). A study made by Asher and Novosad (2016) revealed that road construction led to a movement of households out of agricultural wage labourer, with effects being strongest in villages close to major cities, suggesting the importance of access to labour markets. In view of above discussion, an attempt has been made in this study to examine the advancement of social infrastructure due to the development of rural roads in West Bengal.

\section{DATABASE AND METHODOLOGY}

The study has been conducted based on both primary and secondary data. Secondary data has been collected from Census and Statistical Abstract published by Bureau of Applied Economics and Statistics, Government of West Bengal. The primary data has been collected from two districts. First, the road density of all districts of West Bengal has been examined based on the secondary data. Then all the districts have been sub-divided into two groups i.e. high and low road density.

Howrah and Purulia from high and low road density respectively have been selected randomly. In the next stage, one block from each district i.e. Uluberia-I from Howrah and Para from Purulia have been selected randomly. The list of all villages of the selected blocks have been collected and 
sub-divided into two groups, i.e., (i) proximity to main road and rail station along with presence of paved road and mud road within the villages, and a high population density (Group-1) and (ii) away from main road and rail station and which do not have paved road within the villages but a high population density exist (Group-0). Then two villages from each group i.e. four villages from each district have been selected randomly. In the next stage, list of the households of the selected villages has been prepared and 40 households from each village i.e. 160 households from each district have been selected randomly. Finally, 320 households have been selected as the total sample size of the study.

\section{RESULTS AND DISCUSSION}

Various studies unveiled that development of rural infrastructure leads to socio-economic growth and development in long run by improving the access to essential services. In this study it has been found that $58.14 \%$ belong to Group-1 have acquired education at least 'up to middle school', whereas $42.51 \%$ belonging to Group0 have that level of education (Fig. 1). Table I reveals that better connectivity has an indirect impact on literacy. Higher number of both male female in Group-1 has been found to attend higher secondary schools/technical institutions/colleges etc than group-0.

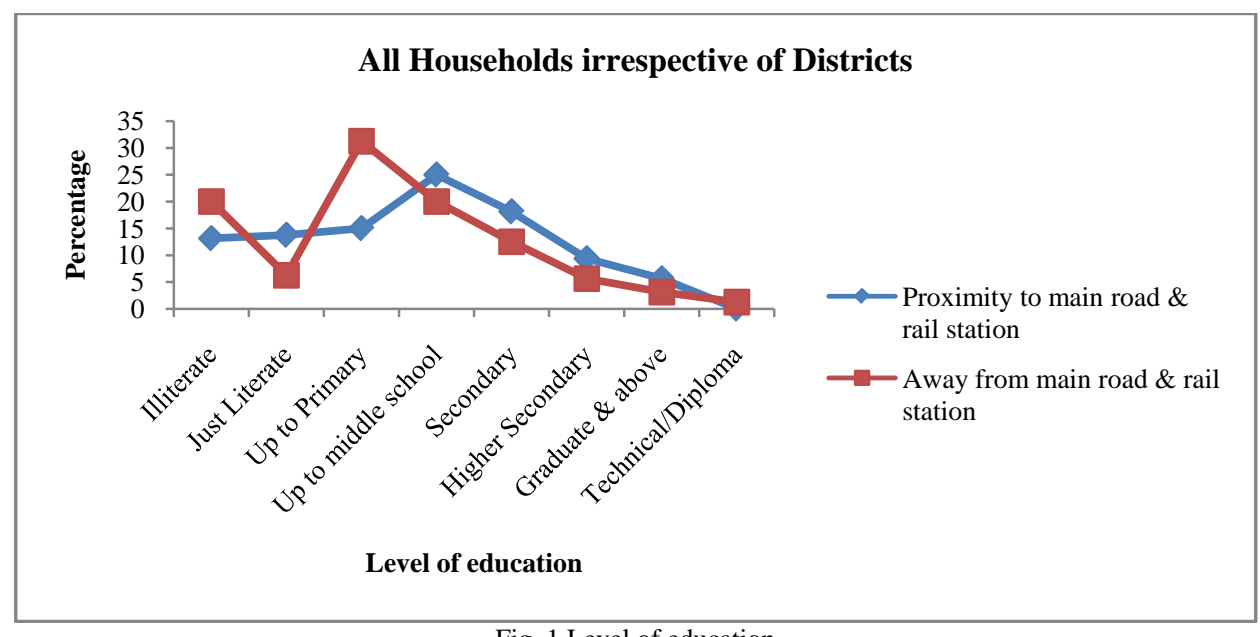

Fig. 1 Level of education

TABLE I ATTAINING HIGHER SECONDARY/COLLEGES/TECHNICAL INSTITUTIONS BY SEX

\begin{tabular}{|l|c|c|c|c|c|c|}
\hline \multirow{2}{*}{ Sex } & \multicolumn{2}{|c|}{ Howrah } & \multicolumn{2}{c|}{ Purulia } & \multicolumn{2}{c|}{ All } \\
\cline { 2 - 7 } & $\begin{array}{c}\text { Villages near to } \\
\text { main road \& } \\
\text { rail station }\end{array}$ & $\begin{array}{c}\text { Villages away } \\
\text { from main road } \\
\text { \& rail station }\end{array}$ & $\begin{array}{c}\text { Villages near to } \\
\text { main road \& rail } \\
\text { station }\end{array}$ & $\begin{array}{c}\text { Villages away } \\
\text { from main road } \\
\text { \& rail station }\end{array}$ & $\begin{array}{c}\text { Villages near to } \\
\text { main road \& } \\
\text { rail station }\end{array}$ & $\begin{array}{c}\text { Villages away } \\
\text { from main road } \\
\text { \& rail station }\end{array}$ \\
\hline Male & 25 & 20 & 17 & 9 & 42 & 29 \\
\hline Female & 15 & 11 & 10 & 5 & 25 & 16 \\
\hline Total & 40 & 31 & 27 & 14 & 67 & 45 \\
\hline
\end{tabular}

TABLE II GROUP STATISTICS FOR EDUCATIONAL STATUS OF THE SELECTED HOUSEHOLDS

\begin{tabular}{|c|c|c|c|c|c|c|c|}
\hline \multirow[b]{2}{*}{ District } & \multirow{2}{*}{ Type of group } & \multicolumn{3}{|c|}{ Group statistics } & \multicolumn{3}{|c|}{ t-test for equality of means } \\
\hline & & $\mathbf{N}$ & Mean & SD & $\mathbf{t}$ & Sig. (2 tailed) & Level of significance \\
\hline \multirow{2}{*}{ Howrah } & 0 & 80 & 3.00 & 0.79242 & \multirow{2}{*}{0.116} & \multirow{2}{*}{0.089} & \multirow{2}{*}{$10 \%$} \\
\hline & 1 & 80 & 4.78 & 0.96113 & & & \\
\hline \multirow{2}{*}{ Purulia } & 0 & 80 & 2.52 & 1.03268 & \multirow{2}{*}{-2.196} & \multirow{2}{*}{0.030} & \multirow{2}{*}{$5 \%$} \\
\hline & 1 & 80 & 2.88 & 0.96683 & & & \\
\hline \multirow{2}{*}{ All } & 0 & 160 & 2.71 & 0.85027 & \multirow{2}{*}{-1.548} & \multirow{2}{*}{0.032} & \multirow{2}{*}{$5 \%$} \\
\hline & 1 & 160 & 3.74 & 0.96314 & & & \\
\hline
\end{tabular}

Group mean comparison method has been adopted as inferential statistics to have an idea regarding the educational status and has been presented in Table II. Mean values of educational status are 3.00 and 4.78 in case of Group-0 and Group-1 respectively for Howrah. Accordingly, the information on t-test shows that the ' $p$ ' 
value is 0.089 and degree of freedom is 158 and the two group means significantly differ at $10 \%$ level of significance.

Mean values are 2.52 and 2.88 in case of Group-0 and Group-1 respectively with 'p' value of 0.030 and the degree of freedom is 158 for Purulia and the two group means significantly differ at $5 \%$ level of significance. The means are 2.71 and 3.74 in case of Group-0 and Group-1 respectively with 'p' value of 0.032 and the degrees of freedom is 318 for full sample (both districts combined) and the two group means significantly differ at $5 \%$ level of significance. All these pointed out that better connectivity leads to significant impact on education.

TABLE III SANITARY CONDITION OF THE HOUSEHOLDS

\begin{tabular}{|c|c|c|c|c|c|c|c|c|}
\hline \multirow[b]{2}{*}{ District } & \multicolumn{4}{|c|}{ Villages near to main road \& rail station } & \multicolumn{4}{|c|}{ Villages away from main road \& rail station } \\
\hline & $\begin{array}{c}\text { Total } \\
\text { number of } \\
\text { households } \\
\text { with } \\
\text { sanitation } \\
\text { facility }\end{array}$ & $\begin{array}{c}\text { Total number } \\
\text { of households } \\
\text { with } \\
\text { permanent } \\
\text { sanitation } \\
\text { facility }\end{array}$ & $\begin{array}{c}\text { Total number } \\
\text { of households } \\
\text { with } \\
\text { temporary } \\
\text { sanitation } \\
\text { facility }\end{array}$ & $\begin{array}{c}\% \text { of } \\
\text { households } \\
\text { having } \\
\text { permanent } \\
\text { sanitation } \\
\text { facility }\end{array}$ & $\begin{array}{c}\text { Total } \\
\text { number of } \\
\text { households } \\
\text { with } \\
\text { sanitation } \\
\text { facility }\end{array}$ & $\begin{array}{c}\text { Total } \\
\text { number of } \\
\text { households } \\
\text { with } \\
\text { permanent } \\
\text { sanitation } \\
\text { facility }\end{array}$ & $\begin{array}{c}\text { Total } \\
\text { number of } \\
\text { households } \\
\text { with } \\
\text { temporary } \\
\text { sanitation } \\
\text { facility }\end{array}$ & $\begin{array}{c}\% \text { of } \\
\text { households } \\
\text { having } \\
\text { permanent } \\
\text { sanitation } \\
\text { facility }\end{array}$ \\
\hline Howrah & 64 & 50 & 14 & 78.13 & 59 & 39 & 20 & 66.10 \\
\hline Purulia & 46 & 32 & 14 & 69.57 & 29 & 15 & 14 & 51.72 \\
\hline All & 130 & 82 & 48 & 63.08 & 88 & 54 & 34 & 61.36 \\
\hline
\end{tabular}

Table III portrays the sanitary condition of the sample households and Fig. 2 presents the detailed picture about the percentage of households with permanent sanitation facility. Table IV shows that higher percentage of houses have permanent sanitation facilities in Group-1. Mean values of two groups for 'Sanitation score' are 0.54 and 0.69 in Group-0 and Group-1 respectively for full sample irrespective of districts. The result also shows that the level of significance is 0.016 at 318 degrees of freedom (TableIV). The two group means for "Sanitation score" significantly differ at $5 \%$ level of significance. It reflects through these analyses that a higher percentage of houses have permanent sanitation facilities in Group 1.

TABLE IV GROUP STATISTICS OF SANITATION CONDITION OF THE HOUSEHOLD

\begin{tabular}{|c|c|c|c|c|c|c|c|}
\hline \multirow{2}{*}{ District } & \multirow{2}{*}{ Type of Group } & \multicolumn{3}{|c|}{ Group statistics } & \multicolumn{3}{|c|}{ t- Test for Equality of Means } \\
\hline & & $\mathbf{N}$ & Mean & SD & $\mathbf{t}$ & Sig. (2 tailed) & Level of significance \\
\hline \multirow{2}{*}{ Howrah } & 0 & 80 & 0.73 & 0.44277 & \multirow{2}{*}{-0.934} & \multirow{2}{*}{0.035} & \multirow{2}{*}{$5 \%$} \\
\hline & 1 & 80 & 0.80 & 0.40252 & & & \\
\hline \multirow{2}{*}{ Purulia } & 0 & 80 & 0.36 & 0.48376 & \multirow{2}{*}{-2.573} & \multirow{2}{*}{0.011} & \multirow{2}{*}{$5 \%$} \\
\hline & 1 & 80 & 0.56 & 0.49921 & & & \\
\hline \multirow{2}{*}{ All } & 0 & 160 & 0.54 & 0.49906 & \multirow{2}{*}{-2.428} & \multirow{2}{*}{0.016} & \multirow{2}{*}{$5 \%$} \\
\hline & 1 & 160 & 0.69 & 0.46745 & & & \\
\hline
\end{tabular}

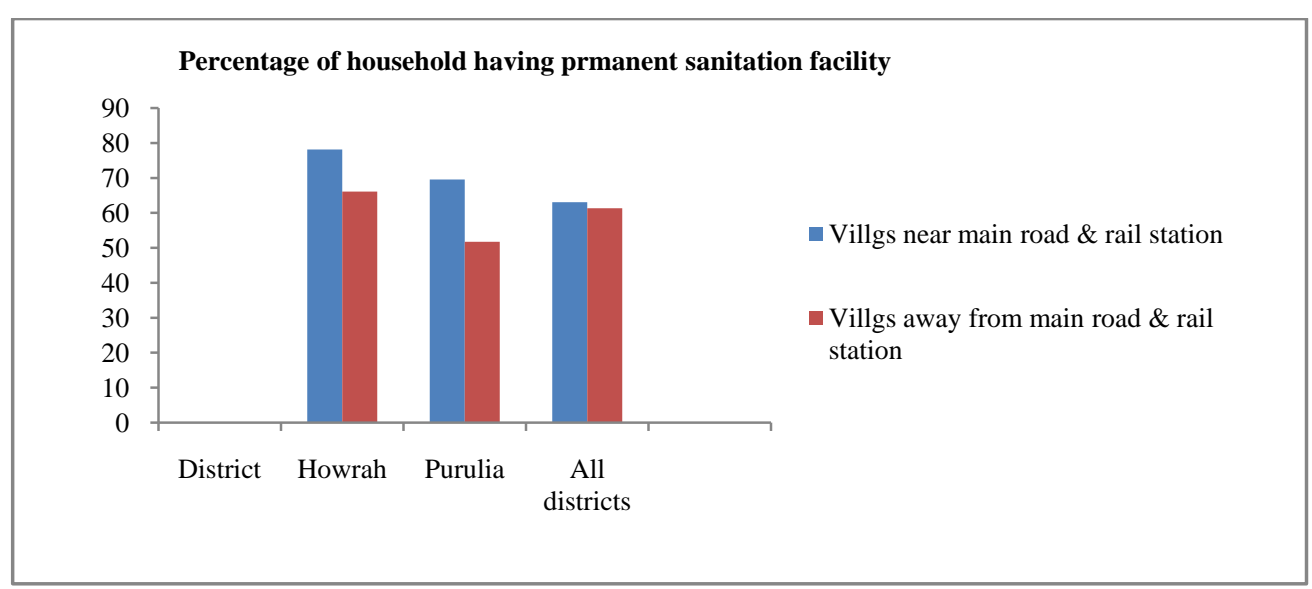

Fig. 2 Percentage of households with permanent sanitation facility 
TABLE V GROUP MEAN COMPARISON FOR DRINKING WATER SCORE

\begin{tabular}{|c|c|c|c|c|c|c|c|}
\hline \multirow{2}{*}{ District } & \multirow{2}{*}{ Type of Group } & \multicolumn{3}{|c|}{ Group statistics } & \multicolumn{3}{|c|}{ t- Test for Equality of Means } \\
\hline & & $\mathbf{N}$ & Mean & SD & $\mathbf{t}$ & Sig. (2 tailed) & Level of significance \\
\hline \multirow{2}{*}{ Howrah } & 0 & 80 & 0.63 & 0.48376 & \multirow{2}{*}{-1.919} & \multirow{2}{*}{0.057} & \multirow{2}{*}{$10 \%$} \\
\hline & 1 & 80 & 0.78 & 0.42022 & & & \\
\hline \multirow{2}{*}{ Purulia } & 0 & 80 & 0.52 & 0.48718 & \multirow{2}{*}{-0.493} & \multirow{2}{*}{0.062} & \multirow{2}{*}{$10 \%$} \\
\hline & 1 & 80 & 0.67 & 0.47584 & & & \\
\hline \multirow{2}{*}{ All } & 0 & 160 & 0.61 & 0.48398 & \multirow{2}{*}{-1.673} & \multirow{2}{*}{0.095} & \multirow{2}{*}{$10 \%$} \\
\hline & 1 & 160 & 0.72 & 0.45102 & & & \\
\hline
\end{tabular}

Accessibility to potable water source is considered as another important factor which affects the quality of life. Accessibility to potable drinking water has been measured by unavailability/availability of drinking water within 100 150 meter and the households have been categorized by 0 or 1 respectively and have been tested statistically by group mean. It has been found that mean of two groups for source of 'Drinking water score' are 0.61 and 0.72 in case of Group-0 and Group-1 respectively for both districts combined and separately (Table V). The result also shows that the 'p' value is 0.095 and degree of freedom is 318. The two group means for 'Drinking water score' significantly differs at $10 \%$ level of significance. Health score has also been examined to know the association of roads on healthcare services relating to health centers, rural subcenters, maternal and child health centers etc. and accordingly 'Health score' has been taken as 1 if the members of the households avail the healthcare facilities outside the village/Gram Panchayet and ' 0 ' as health score if they do not avail the existing facilities inside or outside Gram Panchayet. Table VI reveals that there is a significant improvement in availing public healthcare facilities in case of villages having road connectivity. It has been found that mean values of 'health score' are 0.51 and 0.65 in case of Group-0 and Group-1 respectively for both districts combined. The result shows that the level of significance is 0.013 at 318 degrees of freedom. The two group means for availing healthcare facilities at PHC (Primary health centre)/CHC (Community health centre) etc significantly differs at $5 \%$ level of significance irrespective of districts. This holds true for intra district comparison too.

TABLE VI GROUP MEAN COMPARISON OF HEALTH SCORE OF HOUSEHOLDS

\begin{tabular}{|c|c|c|c|c|c|c|c|}
\hline \multirow{3}{*}{ District } & \multicolumn{7}{|c|}{ Group Statistics of Health score of households } \\
\hline & \multirow{2}{*}{ Type of Group } & \multirow{2}{*}{$\mathbf{N}$} & \multirow{2}{*}{ Mean } & \multirow{2}{*}{ SD } & \multicolumn{3}{|c|}{ t- Test for Equality of Means } \\
\hline & & & & & $\mathbf{t}$ & Sig. (2 tailed) & Level of significance \\
\hline \multirow{2}{*}{ Howrah } & 0 & 80 & 0.50 & 0.50315 & \multirow{2}{*}{-2.444} & \multirow{2}{*}{0.016} & \multirow{2}{*}{$5 \%$} \\
\hline & 1 & 80 & 0.69 & 0.46644 & & & \\
\hline \multirow{2}{*}{ Purulia } & 0 & 80 & 0.52 & 0.50253 & \multirow{2}{*}{-1.115} & \multirow{2}{*}{0.067} & \multirow{2}{*}{$10 \%$} \\
\hline & 1 & 80 & 0.61 & 0.49025 & & & \\
\hline \multirow{2}{*}{ All } & 0 & 160 & 0.51 & 0.50141 & \multirow{2}{*}{-2.509} & \multirow{2}{*}{0.013} & \multirow{2}{*}{$5 \%$} \\
\hline & 1 & 160 & 0.65 & 0.47847 & & & \\
\hline
\end{tabular}

TABLE VII RELATIONSHIP BETWEEN RURAL ROADS AND OTHER IMPORTANT RURAL INFRASTRUCTURE

\begin{tabular}{|l|l|l|}
\hline $\begin{array}{c}\text { Independent } \\
\text { Variable }\end{array}$ & \multicolumn{1}{|c|}{ Dependent Variable } & \multicolumn{1}{c|}{ Type of Relationship } \\
\hline \multirow{5}{*}{ Rural Roads } & Rural deposits at Commercial Banks & Significant relationship at both the districts \\
\cline { 2 - 3 } & Rural advance at Commercial Banks & Significant relationship at both the districts \\
\cline { 2 - 3 } & $\begin{array}{l}\text { Number of cultivators benefitted from } \\
\text { warehouses and cold storages }\end{array}$ & $\begin{array}{l}\text { Very prominent and significant relationship at } \\
\text { poorly connected district like Purulia. Howrah } \\
\text { being relatively developed enjoy locational } \\
\text { advantage. Result is less prominent. }\end{array}$ \\
\cline { 2 - 3 } & $\begin{array}{l}\text { Total number of different sources of } \\
\text { irrigation }\end{array}$ & $\begin{array}{l}\text { Very prominent significant result at poorly } \\
\text { connected district of Purulia, at Howrah the } \\
\text { same is less being more developed and having } \\
\text { better connectivity. }\end{array}$ \\
\hline
\end{tabular}

Source: Statistical Abstract, BAES, Government of West Bengal 
Effort has also been made to understand whether any relationship exists between rural roads other important rural infrastructure by analysing the available secondary data. It has been observed that enrolment in secondary/higher secondary schools increases due to access to rural road (Table VII). Thus road connectivity is one of the factors that increases the enrolment in school which is nothing but a relationship between rural roads and education.

\section{CONCLUSION}

Thus infrastructure investments contribute to economic growth and raise the quality of life by improving the other dimensions of wellbeing. Roads play a vital role by facilitating utilization of existing socio economic services such as education, health services, access to markets, access to drinking water facility, access to institutional credit etc. Better road connectivity raises awareness, personal knowledge leading to improved accessibility to the facilities of health services, further use of sanitation. All these enhance the human capital accumulation to the poor enabling people to pursue different livelihood strategies. Secondary data for different variables also leads to significant results. Therefore it can be stated that rural roads bear a relationship with other social infrastructure and can change rural livelihood pattern.

\section{REFERENCES}

[1] Airey, T. (1989). The impact of road construction on hospital inpatient catchments in the Meru District of Kenya, Social Science and Medicine, 29(1), 95-106.

[2] Agrnor, P. R., \& Blanca, M. D. (2006). Public infrastructure and growth: New channels and policy implications. Banca d'Italia, Italia.

[3] Asher, S., \& Novosad, P. (2016). Market access and structural transformation: Evidence from Rural Roads in India. Retrieved from http://www.eco. uc3m.s/temp/paper\%20Asher.pdf.
[4] Barret, C. B., Reardon, T., \& Webb, P. (2001). Non-farm income diversification and household livelihood strategies in rural Africa: concepts, dynamics and policy implications. Food Policy, 26, 315331.

[5] Gerald, G. (1986). Nepal's road network: A stimulus for economic development, Applied Geography and Development, 28, 84-95.

[6] Jain, P. (2014). Pradhan Mantri Gram Sadak Yojana: A path to inclusive growth of MP. International Journal of Commerce, Business and Management, 13(3), 302-310. Retrieved from http://www.iracst.org/ijcbm/ papers/ vol3no22014/8vol3no2.pdf.

[7] Levy, H. (1996). Kingdom of Morocco: Socioeconomic influence of Rural roads: Fourth Highway Project. Impact Evaluation Report No.15808. Washington, D.C: The World Bank Operation Evaluation Department.

[8] Narayanamoorthy, A., \& Hanjra, M. A. (2006). Rural infrastructure and agricultural output linkages: A Study of 26 Indian Districts. Indian Journal of Agricultural Economics, Indian Society of Agricultural Economics, 61(3), 1-16.

[9] Ramachandran, V.K., \& Swaminathan, M. (2002). Rural banking and landless labour households: Institutional reform and rural credit markets in India. Journal of Agrarian Change, 2(4), 502-544.

[10] Samanta, P. K. (2015). Development of rural road infrastructure in India, Pacific Business Review International, 7(11), 86- 93.

[11] Singh, S., \& Chauhan, V. S. (1984). Regionalisation for rural development and planning. Meerut: Independent Publishing Pvt. Ltd.

[12] Terefe, L. A. (2012). Impact of road on rural poverty: Evidence from fifteen rural villages in Ethiopia. Ethiopia: International Institute of Social sciences.

[13] Tighe, D. (2006). Roads and poverty reduction. Paper presented at the International Seminar on Rural Road Transport, Siem Reap, Cambodia, 15-16 May. Retrieved from www.ruralroads.org/doc/ roadsandpoverty reduction.pdf.

[14] Thorat, Sukhadco., \& Sirohi, Smita. (2002). Rural Infrastructure: State of Indian farmer: A millenium study. New Delhi: Ministry of Agriculture, Government of India,

[15] Werner, F., \& Lucious, G. K. (1992). The influence of transportation infrastructure on the regional pattern of agriculture in West Africa, using as an example the impact of the minor road network in the Dan Hills region of the Ivory Coast. Applied Geography and Development, 39, 30-47. 